\title{
Distribution of biocides in selected marine organisms from South of Johor, Malaysia
}

\begin{abstract}
The emerging of organotins (OTs) have adverse effect toward marine organisms and expose health problem through dietary uptake of contaminated seafood. While the booster biocide creates significant environmental risks mainly on the base of the marine food chain. The present study reported on the baseline data on the level and distribution of organotin and booster biocide in the primary producers (Ulva sp., Enhalus acoroides), mollusks (Strombus turturella, Perna viridis, Pinna nobilis) and fish species (Otolithus ruber, Polydactylus sextarius, Thryssa dussumieri) collected from the seagrass bed of Sungai Pulai estuary. The samples were extracted by mechanical shaking with acetone before analyses using GC-MS. The primary producers of Ulva sp. and Enhalus acoroides have the highest tributyltin (TBT) and mobobutyltin (MBT) concentration with values of $433 \pm 22$ and $35 \mathrm{~g} / \mathrm{kg}$, respectively. Meanwhile, mollusks and fish species have the highest monophenyltin (MPT) concentration which indicated phenyltin (PT) was dominant over butyltin (BT) compound. Dichlorofluanid and M1 are two compounds which mostly detectable in Polydactylus sextarius and Ulva sp. with the highest measured values of $130 \mathrm{~g} / \mathrm{kg}$ and $86 \mathrm{~g} / \mathrm{kg}$, respectively. The elevated biocides detected in the selected marine organisms proved increasing application of these compounds in the shipping system, agricultural runoff, and domestic activities.
\end{abstract}

Keyword: Organotin; Booster biocides; Antifouling paint; Marine organisms; Seagrass 